\title{
BUSINESS PERFORMANCE AND COMPETITIVE ADVANTAGE: MULTI PERSPECTIVE ANALYSIS OF SMES IN BALI
}

\author{
N. W. Sukartini, A. A. A. M. Kencanawati, N. K. Lasmini \\ Associate Professor, Business Administration Department, \\ Bali State Polytechnic, Indonesia
}

\begin{abstract}
The aims of this paper are to analyze business performance and competitiveness of SMEs in Bali from the perspective of human resource competency and market orientation. This research was conducted with 100 owners of SMEs of wood craft in Bali. The data were collected through interview, observation, questionnaire, and documentation, then analyzed using the following techniques: (1) descriptive statistic; and (2) structure equation models. The results of the analysis show that: (1) the business performance and competitiveness of SMEs are categorized as fair; (2) Human resource competency has a positive and significant effect on market orientation and business performance of SMEs; (3) business performance has a positive and significant effect on the competitiveness of SMEs; (4) market orientation has a positive and significant effect on the business performance and competitiveness of SMEs. The relevant suggestions for this study are (1) improving HR managerial skills by participating in training; (2) improving product quality by minimizing costs through innovation; (3) Empowering the government to play a role in helping SMEs to open market access.
\end{abstract}

Keywords: SMEs, Business Performance, Competitive Advantage Market Orientation

Cite this Article: N. W. Sukartini, A. A. A. M. Kencanawati, N. K. Lasmini, Business Performance and Competitive Advantage : Multi Perspective Analysis of SMES in Bali, International Journal of Management (IJM), 10 (6), 2019, pp. 105-113.

http://iaeme.com/Home/issue/IJM?Volume $=10 \& I s s u e=6$

\section{INTRODUCTION}

Human Resources (HR) are the main driving factors of a business. The development of a business such as SMEs is largely determined by the quality of the HR management. According to [1] managerial skills, leadership abilities, financial management skills are very influential on the overall performance of MSMEs. [2] States that good managerial management of small businesses will have an impact on SME performance. Customer's desire is very important in product marketing. Paying attention to customer's desire and treat it as a market orientation will enable SMEs to understand its needs. As stated by [3], that market orientation is the orientation of a company using the underlying principle to satisfy the needs and wants of consumers. Relationship between market orientations with thoroughly elaborated. [4] Finds a positive 
relationship between market orientation and business profitability, and [3] study found that the greater the market orientation of an organization, the greater the overall performance will become. According to [5] innovation and market orientation can contribute to the improvement of business performance of SMEs. In addition to these results, many theories and research results show that there is a very positive relationship between performance and competitiveness. Among these prominent studies is [6] which states that competitive advantages are those factors that a firm needs to have in order to succeed in business, and competitive advantage is the heart of business performance in competitive markets

The condition of SMEs in Bali is almost the same as the state of SMEs in general, namely in management. The problems are the performance and competitiveness of SMEs in Bali, how does it perform and how competitive is it?. This study is expected to answer the following (1) the performance and competitiveness of SMEs in Bali; (2) the influence of human resource competencies on market orientation and the performance of SMEs; (3) the effect of performance on the competitiveness of SMEs; (4) the influence of market orientation on the performance and competitiveness of SMEs.

\section{LITERATURE REVIEW}

According to [5], human resource competencies are competencies related to knowledge, skills, abilities and personality characteristics that directly affect their performance. [7] and [8] formulated several indicators to determine the competencies of HR owned by business actors, including: (1) education level; (2) experience in the business world; (3) education related to the business world; (4) competency in managing finances; (5) competency in marketing; and (6) general managerial competency

Market Orientation, according to [9], is a marketing concept supported by four pillars, namely target market, consumer needs (focus on consumers), integrated marketing, and profitability. [9] further defines market orientation as a response to market changes. Market orientation is significantly an important factor that enables companies to understand the market and to develop product and service strategies to meet customer needs and those of the market [10]. [11] argued that greater emphasis on customer orientation indeed increases the introduction of new products to the world. Market orientation is very important for micro and small businesses in order to obtain a sustainable competitive advantage by relating the degree of market orientation to the extent of success in achieving critical performance outcomes [12].

[23] stated that performance is the achievement of the company within a specific period of time which reflects the level of health of the company. According to growth dimension is known as the most important measure of performance, especially for smaller companies, and constitutes a test of a good performance amidst economic recession and intense competition. The sales growth is a very common indicator of performance and has become an agreed-upon measure of growth. Growth in market share can be used to measure the effectiveness of the market. Profit growth is also an important indicator of growth and can reflect the company's financial performance. Indikator untuk mengukur business performance usaha mikro dan kecil adalah a) increase number of employed; b) increase in production; c) development of business units; d) increase in volume; e) profitability [13],[14],[15]

Competitive advantage is the one that characterizes and makes something better than all its competitors [16]. Competitive advantage is the capability of the organization to do its activity in a way or in different ways, that other competitors can not realize [9]. According to [17] competitive advantage means that the firm can produce goods or services that their customers find more valuable than the goods or services produced by their competitors. The dimension of competitive advantage includes cost, quality, and delivery [18]. Competitive advantages can be created through innovation, efficiency, quality, and customer responsiveness [19]. In an intense 
market, competitive advantage is necessary for SMEs operation, especially in the emerging market, to sustain high performance [20].

\section{RESEARCH METHODOLOGY}

Research focused on the wooden craft SMEs in Bali, Indonesia with the population of 238 business allover Bali. The study accommodates 100 owners of SMEs of wood craft with proportional random sampling. Several instruments are employed in data collection: interview, observation, questionnaire, and documentation, then analyzed by the following techniques: (1) descriptive statistic; and (2) structure equation models with smartpls-3 software.

\subsection{Research Conceptual Framework}

Based on the theories and research findings that have been described above, it was possible to describe a concept and the development of hypotheses in this study. The research model can be determined as shown in Fig. 1 below

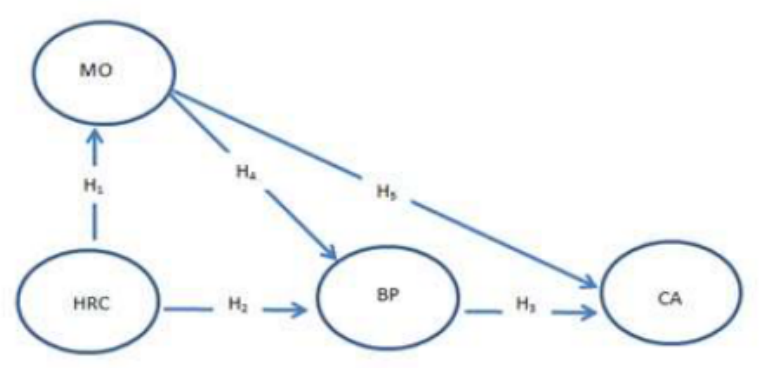

Figure 1. Research Conceptual Framework

\subsection{Hypothesis}

H1 : human resource competency will have a positive and significant effect on market orientation;

$\mathrm{H} 2$ : human resource competency will have a positive and significant effect on business performance.

H3 : business performance will have a positive and significant effect on market orientation

$\mathrm{H} 4$ : market orientation will have a positive and significant effect on business performance

H5 : market orientation will have a positive and sgnificant effect on competitive advantage

\subsection{Measurement of the Variables}

The variables in this study were measured from the constructs (latent variables) Human Resource Competency (X1), Market Orientation (Y1), Business Performance (Y2), and Competitive advantage (Y3). Each construct consists of several measurable variables as shown in Table 1.

Table 1. Measurable of Variables

\begin{tabular}{|c|c|}
\hline $\begin{array}{c}\text { Construct } \\
\text { ( Latent Variable) }\end{array}$ & Measurable Variables \\
\hline Human Resource Competency $(\mathrm{X} 1)$ & Level of education $\left(\mathrm{X}_{1.1}\right)$ \\
\hline & Eexperience in the business world $\left(\mathrm{X}_{1.2}\right)$ \\
\hline & Eeducation related to the business world \\
\hline & Ccompetency in managing finances $\left(\mathrm{X}_{1.3}\right)$ \\
\hline
\end{tabular}




\begin{tabular}{|c|c|}
\hline & Ccompetency in marketing $\left(\mathrm{X}_{1.4}\right)$ \\
\hline & General Mmanagerial competency $\left(\mathrm{X}_{1.6}\right)$ \\
\hline Market Orientation (Y1) & Customer orientation $\left(\mathrm{Y}_{1.1}\right)$ \\
\hline & Competitor orientation $\left(\mathrm{Y}_{1.2}\right)$ \\
\hline & Interfunctional coordination $\left(\mathrm{Y}_{1.3}\right)$ \\
\hline Business Performance (Y2) & Increase in workforce $\left(\mathrm{Y}_{2.1}\right)$ \\
\hline & Increase in Sales Turnover $\left(\mathrm{Y}_{2.2}\right)$ \\
\hline & Increase in Venture Capital $\left(\mathrm{Y}_{2.3}\right)$ \\
\hline & Increase in Profit $\left(\mathrm{Y}_{2.4}\right)$ \\
\hline & Market Expansion $\left(\mathrm{Y}_{2.5}\right)$ \\
\hline Competitive Advantage (Y3) & Cost $\left(\mathrm{Y}_{3.1}\right)$ \\
\hline & Quality $\left(\mathrm{Y}_{3.2}\right)$ \\
\hline & Delivery $\left(\mathrm{Y}_{3.3}\right)$ \\
\hline
\end{tabular}

\section{RESULTS AND DISCUSSIONS}

\subsection{The Performance of SMEs in Bali}

The data analysis shows that in general the performance of the wooden craftsmanship SMEs in Bali belonged to the "fair" category with an average score achievement of 2.48 as shown in the following Table 2

Table 2. The Performance of SMEs in Bali

\begin{tabular}{|c|c|c|c|}
\hline No. & Performance Indicator & Average & Remark \\
\hline 1 & Increase in workforce & 2.6 & Good \\
\hline 2 & Increase in Sales Turnover & 2.5 & Good \\
\hline 3 & Increase in Venture Capital & 2,6 & Good \\
\hline 4 & Increase in Profit & 2,5 & Good \\
\hline 5 & Market Expansion & 2,2 & Fair \\
\hline \multicolumn{2}{|r|}{ Average } & 2.48 & Fair \\
\hline
\end{tabular}

Table 2 shows that from the five indicators used to measure the performance of SMEs, it turns out that the indicator of market expansion is not good enough.

\subsection{Competitiveness of SMEs}

There are three indicators used to measure competitiveness, namely cost, quality, and delivey. The result of the analysis shows that SMEs is fair competitive which can be seen from the average achievement of the score of 2.49 as shown in Table 3

Tabel 3. Competitiveness Of Smes

\begin{tabular}{|c|c|c|c|}
\hline No. & Competitiveness Indicator & Average & Remark \\
\hline 1 & Cost & 2.4 & Good \\
\hline 2 & Quality & 2.5 & Good \\
\hline 3 & Delivery & 2,4 & Fair \\
\hline & Average & 2.43 & Fair \\
\hline
\end{tabular}

Table 3 shows that the lack of competitiveness of SMEs in wooden handicrafts in Bali is caused by delivery indicators. 


\subsection{The Relationship Between Variable}

\subsubsection{Assessment of the Measurement (Outer) Model}

The measurement (outer) model shows how each indicator block relates to its latent variable (construct). There are several tests that can be used to see the significance of each indicator making up a construct, namely test of validity and test of reliability. Test of Validity: To determine the validity of each indicator of a construct can be seen from the convergent validity and determinant validity. Convergent validity of a measurement model with reflective indicators can be seen from the correlation between item / indicator scores and the construct scores. Individual indicators are considered reliable in a research, if the loading scales range 0.50 to 0.6 , and thus are still acceptable. Table 4 shows that all indicators in the human resource competency (HRC), market orientation (MO), business performance (BP) and competitive advantage (CA) constructs were valid constructs because they have a loading factor of $>0.50$.

Table 4. Outer Loding Coefficient for Each Indicator

\begin{tabular}{|c|c|c|c|c|}
\hline & BP & $\mathrm{CA}$ & HRC & $\mathrm{MO}$ \\
\hline $\mathrm{X} 1.1$ & & & 0.669 & \\
\hline $\mathrm{X} 1.2$ & & & 0.770 & \\
\hline $\mathrm{X} 1.3$ & & & 0.829 & \\
\hline $\mathrm{X} 1.4$ & & & 0.774 & \\
\hline $\mathrm{X} 1.5$ & & & 0.846 & \\
\hline X1.6 & & & 0.854 & \\
\hline Y1.1 & & & & 0.860 \\
\hline Y1.2 & & & & 0.875 \\
\hline Y1.3 & & & & 0.887 \\
\hline Y2.1 & 0.819 & & & \\
\hline $\mathrm{Y} 2.2$ & 0.844 & & & \\
\hline Y2.3 & 0.862 & & & \\
\hline Y 2.4 & 0.785 & & & \\
\hline $\mathrm{Y} 2.5$ & 0.644 & & & \\
\hline Y3.1 & & 0.837 & & \\
\hline Y3.2 & & 0.884 & & \\
\hline Y3.3 & & 0.833 & & \\
\hline
\end{tabular}

Another way to measure the validity of each indicator of a construct is to look at the discriminantt validity by looking at the AVE value. The model is considered good if the AVE value of each construct is $>0.50$. Table $\mathrm{V}$ shows the AVE values for all constructs: business performance (BP), competitive advantage (CA), human resource competency (HRC) and market orientation $(\mathrm{MO})$ were greater than 0.50 .

Table 5. Ave Values

\begin{tabular}{|c|c|c|}
\hline & AVE & Akar AVE AVE \\
\hline BP & 0.632 & 0.795 \\
\hline CA & 0.726 & 0.852 \\
\hline HRC & 0.628 & 0.793 \\
\hline MO & 0.764 & 0.874 \\
\hline
\end{tabular}

Test of Reability: The construct reliability test was carried out with two criteria, namely composite reliability and cronbach alpha from the indicator block. Constructs are said to be reliable if the composite reliability and Cronbach alpha values are greater than 0.70 . Table 6 shows that the constructs business performance, competitive advantage, human resource competency and market orientation were reliable. 
Table 6. Composite Reliability and Cronhbach Alpha Coefficients

\begin{tabular}{|c|c|c|}
\hline & Composite Reliability & Cronbachs Alpha \\
\hline BP & 0.895 & 0.851 \\
\hline CA & 0.888 & 0.811 \\
\hline HRC & 0.910 & 0.880 \\
\hline MO & 0.907 & 0.846 \\
\hline
\end{tabular}

\subsubsection{Assessment of the Structural Model (Inner Model)}

The assessment of the structural model was done by looking at the R-square value which is a goodness-fit model test. The magnitude of the influence of Human Resource Competency on Market Orientation is $0.699(69.9 \%)$; and the effect of market orientation on Competitive Advantage is 0.492 (49.2\%). The model of the effect of business performance on competitive advantage yielded a value of $0.473(47.7 \%)$ and $0.437(43.7 \%)$ was influenced by human resource competency and market orientation, as seen in Fig. 2.

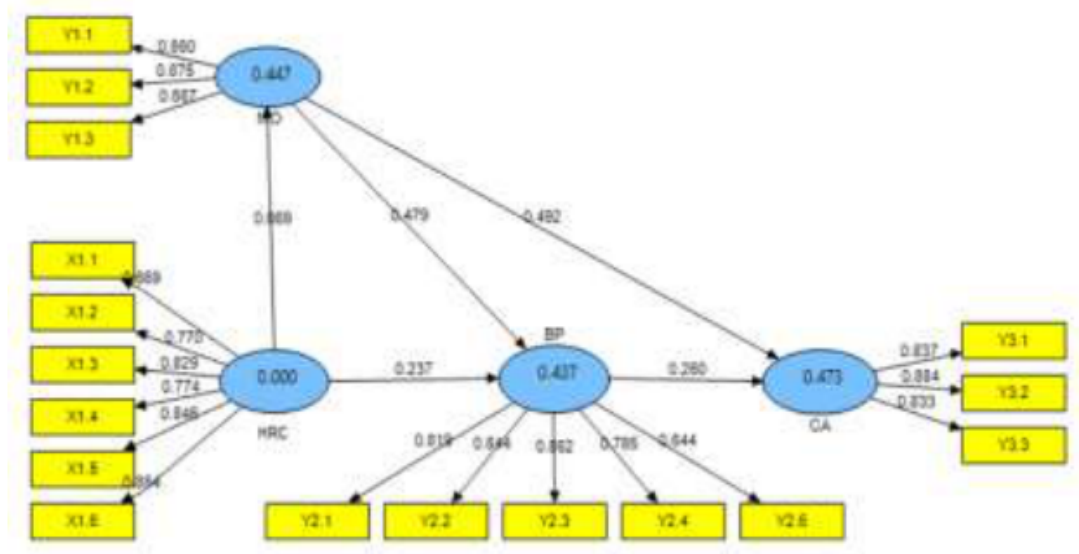

Figure 2. Outer Loading and Path Analysis

\subsubsection{Hypotesis Testing}

This research was conducted to examine the effect of Human Resource Competency and Market Orientation on Business Performance and Competitive Advantage. (Case Study of Small and Micro Industry of Wood Craft in Gianyar Regency). The significance of the effect of the construct can be seen from the results of statistical tests as shown in Fig. 3 and Table 7:

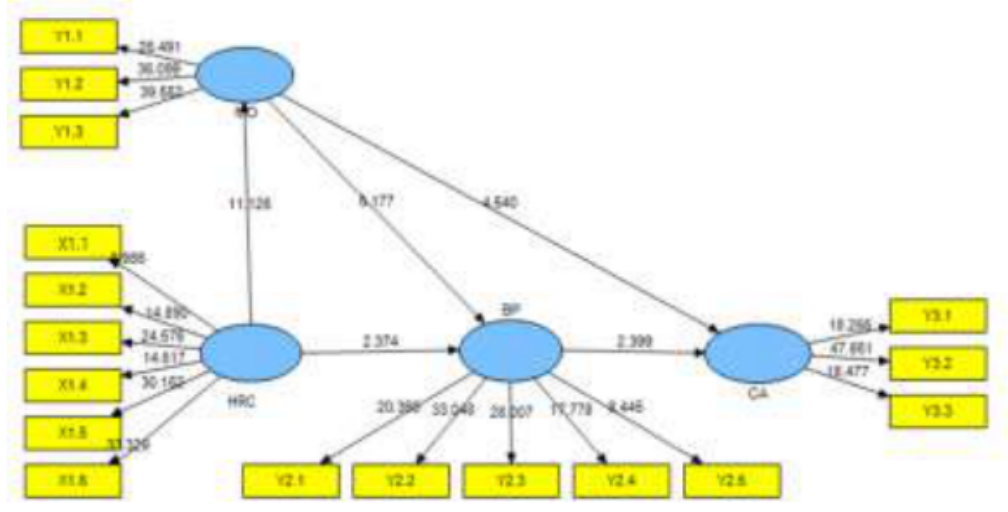

Figure 3. Bootstrapping Model 
Table 7. Path Coefficients (Mean, Stdev, T-Values)

\begin{tabular}{|c|c|c|c|c|c|}
\hline & $\begin{array}{c}\text { Original } \\
\text { Sample (O) }\end{array}$ & $\begin{array}{c}\text { Sample } \\
\text { Mean } \\
(\mathbf{M})\end{array}$ & $\begin{array}{c}\text { Standard } \\
\text { Deviation } \\
\text { (STDEV) }\end{array}$ & $\begin{array}{c}\text { Standard } \\
\text { Error } \\
\text { (STERR) }\end{array}$ & $\begin{array}{c}\text { T Statistics } \\
\text { (|O/STERR|) }\end{array}$ \\
\hline BP -> CA & 0.260 & 0.287 & 0.108 & 0.108 & 2.399 \\
\hline HRC - - BP & 0.557 & 0.566 & 0.076 & 0.076 & 7.321 \\
\hline HRC -> CA & 0.474 & 0.479 & 0.061 & 0.061 & 7.772 \\
\hline HRC -> MO & 0.669 & 0.662 & 0.060 & 0.060 & 11.126 \\
\hline MO -> BP & 0.479 & 0.485 & 0.093 & 0.093 & 5.177 \\
\hline MO -> CA & 0.617 & 0.609 & 0.074 & 0.074 & 8.336 \\
\hline
\end{tabular}

- The relationship between Human Resource Competency and Market Orientation was positive and significant. This can be seen from the t-statistic value of 11,126 ( $>$ 1.96). Thus it can be concluded that there was a positive and significant effect of Human Resource Ability on Business Performance, and this means that the $\mathrm{H}_{1}$ hypothesis was accepted.

- The relationship between Human Resource Competency and Business Performance was positive and significant. This can be seen from the t-statistic value of 7,321 ( $>$ 1.96). Thus it can be concluded that there was a positive and significant effect of Market Orientation on Business Performance, and this means that the hypothesis $\mathrm{H}_{2}$ was accepted.

- The relationship between Business Performance and Competitive Advantage was positive and significant. This can be seen from the t-statistic value of 2.399 ( $>1.96)$. Thus it can be concluded that there was a positive and significant effect of Business Performance on Competitive Advantage, and this means that the $\mathrm{H} 3$ hypothesis was accepted.

- The relationship between Market Orientation and Business Performance was positive and significant. This can be seen from the t-statistic value of 5,177 (>1.96). Thus it can be concluded that there was a positive and significant effect of Human Resource Ability on Competitive Advantage, and this means that the H4 hypothesis was accepted.

- The relationship between Market Orientation and Competitive Advantage was positive and significant. This can be seen from the t-statistic value of $8,336(>1.96)$. Thus it can be concluded that there was a positive and significant effect of Market Orientation on Competitive Advantage, and this means that the H5 hypothesis was accepted

From the analysis described above, it needs to be discussed further regarding business performance and competitive advantage. Poor performance of SMEs wooden crafts in Bali is due to the weakness in market expansion. The in-depth interviews with entrepreneurs shows the lack of the ability to build networks. According to [21], building networks is very important in increasing competitiveness. A social network consists of a series of formal and informal ties between the central actor and other relevant actors in a circle of acquaintances and representative through which entrepreneurs get access to the necessary resources for business start-up, growth and success.

The competitiveness's weakness of SMEs is indicated by cost and delivery. The timber working industry is primarily thandmade which requires skills, art, and in the process requires a relatively longer time than the machine. The working can not be mass produced, using technology such as machines. This is one of the problems that causes higher cost and longer 
time. To be able to compete, the SMEs requires an innovation to reduce production costs. [22], states that innovation is the key to success in improving business competitiveness. The weakness in competitiveness is also due to the lack of on time delivery. Inaccuracies often occur when sending cutomers' orders, especially when the order of goods is in large quantities. There is no mass production in relation to products making. In addition to this, the competence of human resources determines the ability in market orientation, business performance and competitive advantage. This means that to have competitiveness the main factor that must be addressed is human resources, as stated by [7].

\section{CONCLUSION AND RECOMENDATION}

On the basis of the discussion above, it can be concluded that: The results of the analysis show that: (1) the business performance and competitiveness of SMEs is categorized as fair; (2) Human resource competency has a positive and significant effect on market orientation and business performance of SMEs; (3) business performance has a positive and significant effect on the competitiveness of SMEs; (4) market orientation has a positive and significant effect on the business performance and competitiveness of SMEs.

The following suggestions are relevant to the prevailing SMEs (1) improving HR managerial skills by participating in training; (2) improving product quality by minimizing costs through innovation; (3) Empowering the government to play a role in helping SMEs to open market access.

\section{REFERENCES}

[1] J. Ngugi, R. W. Karanja, W. M. Gakure, K. C. Susan, Robinson. The influence of intellectual capital on the growth of small and medium enterprises in Kenya, Journal of Business Management and Corporate Affairs, 1(1), 2012, pp. 11-19.

[2] G. A. Metts. Measuring effectiveness of managerial action in SMEs, Management Research News, 30(12), 2007, pp. 892-914

[3] K. Kohli, B.J. Jaworski, A. Kumar. Markor: measure of market orientation, Journal of Marketing Research, 30(4), 1993, pp. 467-478.

[4] J. C. J. Narver, S. S. F. Slater., The effect of market orientation on business profitability Journal of Marketing, 54(4), 1990, pp. 20-35

[5] A. P. Mangkunegara. Evaluation of Human resources, PT. Refika Aditama, Bandung, 2012, pp. 40

[6] F. Analoui, A. Karami. Strategic Management. In small and Medium Enterprises,. Thomson Learning, 2003

[7] O. O. Fatok. The Impact of human, social and financial capital on the performance of small and medium-sized enterprises (SMEs) in South Africa, Kamla-Raj J Soc Sci, 29(3), 2011, pp. 193-204

[8] I.D.K.R. Ardiana, I.A. Brahmayanti, Subaedi. Human resource conpetency and the influence on business performance of SMEs in surabaya, Journal of Management and Entrepreneurship, 12(1), 2010, pp. 42-55.

[9] P. Kotler, A. B. Susanto. Marketing Management in Indonesia, Jakarta Salemba Empat, Pearson Edication, Asia Pte.Ltd. Pretice Hall. Inc:8, 2003

[10] W. E. Baker, J.M. Sinkula. The complementary effects of market orientation and entrepreneurial orientation on profitability in small business, Journal of Small Business Management, 47(4), 2009, pp.443-464

[11] B. A. Lukas, O. C. Ferrell. The effect of market orientation on product innovation, Journal of the Academy of Marketing Science, 28(2), 2000, pp. 239-247

[12] N. A. Aziz, N. M. Yassin. How will market orientation and external environment influence the performance among SMEs in the agro-food sector in Malaysia?, International Business Research, 3(3), 2010

[13] P. Foley, H. Green. Small business success, , London Chapman, 1989 
[14] J. Wiklund, D. Shepherd. Entrepreneurial orientation and small business performance aconfiguration approach, J Bus Ventur, 2005 pp. 71-91.

[15] M. A. Islam, M. A. Khan, A. Z. M. Obaidullah, M.S. Alam. Effect of Entrepreneur and Firm Characteristics on the Business Success of Small and Medium Enterprises (SMEs) in Bangladesh, International Journal of Business and Management 6(3), 2011, pp. 290

[16] D. Sakas, D. Vlachos, Nasiopoulos. Modelling strategic management for the development of competitive advantage, based on technology, Journal of Systems and Information Technology, 6(3), 2014, pp.187-209

[17] G. Saloner, S. Andrea, P. Joel. Strategic Management, New York: John Wiley \& Sons, 2001

[18] W. Chamsuk, T. Phimonsathien, W. Fongsuwan. Research and development (R\&D) capabilities and innovation capability that affect the enterprise competitive advantage in the thai automotive parts industry: sem approach, International Journal of Arts \& Sciences, 8(02), 2015, pp. 441-457

[19] M. S. Attiany. Competitive advantage through benchmarking: field study of industrial companies listed in amman stock exchange, Journal of Business Studies Quarterly 5(4), 2014, pp. 41-51.

[20] Anwar, Muhammad, S. K. Zaman, N. U. Khan. Intellectual capital, entrepreneurial strategy and new venture performance: mediating role of competitive advantage, Business Economic Review 10: 2018, pp. 63-94

[21] S, Kristiansen, Social network and business success: the role of sub-cultures in an African context, American Journal of Economics and Sociology, 2003

[22] S.M. Shapiro. Innovation: A blue print for surviving and thriving in age of change, New York: Donnelly and Sons Company, 2002.

[23] R. L. Malthis, J. H. Jackson. Human Resource Management (Manajemen Sumber Daya Manusia, Edisi Sepuluh, Terjemahan : Diana Angelica, Penerbit : Salemba Empat, Jakarta, 2006

[24] Smitha Nair, Measuring Entrepreneurial Orientation \& Business Performance Relationship In An Indian Setting, International Journal of Management (IJM), Volume 4, Issue 4, JulyAugust (2013).

[25] Rusdi Hidayat N, Bambang Widjanarko Otok, Roy Kurniawan, Moderating Entrepreneurship at Corporate Reputation in Business Performance using Partial Least Square, International Journal of Mechanical Engineering and Technology 9(8), 2018, pp. 348-358.

[26] Angelina Eleonora Rumengan, Jemmy Rumengan, Chablullah Wibisono and Bambang Widjanarko Otok, Structural Equation Modeling in Business Performance through Competitive Advantage with Information Technology as Moderatin, International Journal of Mechanical Engineering and Technology, 9(10), 2018, pp. 632-644.

[27] M.D.Nadar, Dr. D.N.Raut, Dr. B.E.Narkhede and Dr.S.K.Mahajan, Success Factors Enhancing Business Performance Of Engineering Procurement Construction (Epc) Industries, International Journal of Mechanical Engineering and Technology (IJMET), Volume 4, Issue 1, January - February (2013)

[28] Dr. Musaddag A.H. Elrayah, the Relationship between Integrated Marketing Communications (IMC), Brand Equity \& Business Performance: Evidence from Saudi's Telecommunication Sector. International Journal of Marketing and Human Resource Management, 8(4), 2017, pp. 14-21.

[29] Sherif Mostafa and Jantanee Dumrak, Synergistic Supply Chain for Prefabricated House Building in Developing Countries, International Journal of Advanced Research in Engineering and Technology (IJARET), Volume 5, Issue 1, January (2014) 